\title{
SYNTHESIS, ANTIBACTERIAL AND ANTI-COROSSIVE ACTIVITY OF 2,3-DIHYDROIMIDAZO[1,2-A]PYRIDINIUM BROMIDES
}

\author{
Nataliya Demchenko ${ }^{1,}{ }^{凶}$, Svitlana Tkachenko', Sergii Demchenko ${ }^{2}$
}

https://doi.org/10.23939/chcht14.03.327

\begin{abstract}
The paper describes the synthesis of a set of new 2,3-dihydroimidazo[1,2- $a]$ pyridinium bromides which demonstrate antibacterial properties against sulfatereducing bacteria of Desulfomicrobium and Desulfovibrio strains and inhibit their functioning in the binary culture under the steel microbial corrosion. The compounds demonstrate antibiofilm and anticorrosive properties in the medium with sulfate-reducing bacteria, steel anticorrosion rate is up to $70.6 \%$.
\end{abstract}

Keywords: 2,3-dihydroimidazo[1,2-a]pyridinium bromides, sulfate-reducing bacteria, strain Desulfovibrio sp. M-4.1, strain Desulfomicrobium sp. TC 4, inhibitor-biocides, biocorrosion.

\section{Introduction}

The synthesis of heterocyclic compounds and condensed heterocyclic systems, which are of practical value, is important for the search of biologically active compounds and pharmacophores used to develop new drugs. The new promising class of compounds is 2,3dihydroimidazo[1,2-a]pyridinium derivatives and their salts. Imidazopyridinium salts are important pharmacophores in drug development. They demonstrate wide range of biological activity: they are neuromuscular blockers [1], they reactivate acetylcholinesterase [2], act as antagonists of neuropeptide receptor S for treating sleep disorders, anxiety and drug addiction [3] and hypoglycemic agents [4]. The herbicidal activity of imidazo[1,2- $a$ ] pyridinium salts was established [5].

Heterocyclic $\mathrm{N}$-aryl amidines can exist in two amino-imino tautometric forms. This tautomerization was studied using IR and UV-spectroscopy, PMR-spetrometry, and also by X-ray crystallography analysis. Thus, with the help of IR-spectroscopy it was defined that solidstate 2-anilinopyridine exists in amino-imino forms with prevailing of amino form [6].

\footnotetext{
${ }^{1}$ Taras Shevchenko "Chernihiv Collegium" National University,

53, Hetmana Polubotka St., 14013 Chernihiv, Ukraine

${ }^{2}$ Institute of pharmacology and toxicology of NAS of Ukraine,

14, Antona Tsedyka St., 03057 Kyiv, Ukraine

nata_demch@ukr.net

(c) Demchenko N., Tkachenko S., Demchenko S., 2020
}

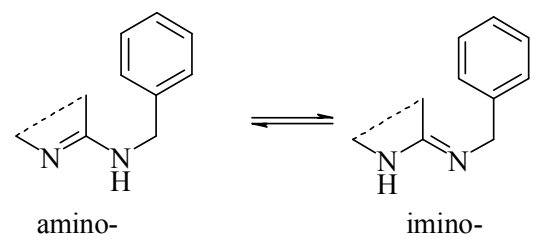

The substitution of arylamino group in 2-arylamino-5,6-dihydrate- $4 H$-1,3-thiazines by benzylamino group leads to the realization of solely amino-form according to the results of X-ray crystallography analysis. Kuhla et al. [7] found that 2-arylamino- and 2-benzylaminopyridines react with chloroacetone and phenacyl bromide on nitrogen atom in the cycle of amidine compounds. So, 2,3-dihydroimidazo[1,2- $a]$ pyridinium derivatives and their salts, which contain quaternary nitrogen, have interesting properties. This offers bright prospects for the purposeful synthesis of compounds of practical value, in particular, biocides-inhibitors of steel microbial corrosion.

One of the most dangerous types of microbial corrosion is the destruction of metal constructions under the influence of sulfate-reducing bacteria (SRB), which reproduce actively in the biofilm under anaerobic conditions $[8,9]$. To protect the metals against the microbial corrosion, the inhibitors-biocides are used, which can inhibit functioning of corrosively active bacteria, sulfate-reducing bacteria in particular, and decelerate the rate of metal microbial corrosion. During the search of inhibitors with biocidal activity it is important to consider the microbiological composition of the corrosive medium, which defines its aggressiveness. The effectiveness of the inhibitors of steel microbial corrosion is determined by its ability to prevent bacteria adhesion to metal surface, inhibit the formation of the biofilm and contribute to its disorganization.

According to the data from our research and other sources [8, 10-13], the most promising and effective inhibitors-biocides of microbial corrosion of steel, induced by sulfate-reducing bacteria, are heterocyclic compounds, containing nitrogen.

We demonstrated [11], that 2,3-dihydroimidazo[1,2a]pyridinium bromides are promising for prevention of steel corrosion in the medium with sulfate-reducing bacteria of Desulfovibrio and Desulfomicrobium strains. 
This paper aims to describe the synthesis of new 2,3-dihydroimidazo[1,2-a]pyridiniums and study their properties: antibacterial against sulfate-reducing bacteria of Desulfomicrobium sp. TC 4 and Desulfovibrio sp. M-4.1 strains in the composition of a binary culture with different component ratios and anticorrosive.

\section{Experimental}

\subsection{Chemistry}

All solvents were purified before use. 2-Benzylaminopyridine was purchased from Acros Organics and used without purification. $\alpha$-Bromoacetophenones were obtained by bromination of the corresponding acetophenones by standard methods [14-18]. Reactions were monitored by thin-layer chromatography (TLC) using Fluka silica gel (60 F 254) plates $(0.25 \mathrm{~mm})$. Visualization was made with UV light. Elemental analysis was performed on a EuroEA 3000 elemental analyzer. The ${ }^{1} \mathrm{H}$ NMR spectra were recorded on a Varian Gemini $400 \mathrm{MHz}$ device in $\mathrm{DMSO}^{-\mathrm{d}_{6}}$ using tetramethylsilane (TMS) as an internal standard. Chemical shifts were reported in ppm units using $\delta$ scale.

Synthesis of 1-benzyl-2-hydroxy-2-phenyl-2,3dihydroimidazo[1,2-a]pyridinium bromide 4a.

Method A: $1.99 \mathrm{~g} \quad(0.01 \mathrm{~mol})$ of $\alpha$-bromoacetophenone $2 \mathbf{a}$ were added under stirring to the solution of 2-benzylaminopyridine 1a (1.84 g, $0.01 \mathrm{~mol})$ in $50 \mathrm{ml}$ of ethyl acetate. The mixture was refluxed for $1 \mathrm{~h}$. The reaction mixture was cooled. The precipitate was filtered off and crystallized from propanol-2. Yield $2.80 \mathrm{~g} \mathrm{(73 \% ).}$ M.p. $=467-468 \mathrm{~K}$. Anal. Calcd. for $\mathrm{C}_{20} \mathrm{H}_{19} \mathrm{BrN}_{2} \mathrm{O}$, \%: $\mathrm{N}=7.30 \mathrm{Br}=20.8$. Found, \%: $\mathrm{N}=7.53 \mathrm{Br}=20.5$. ${ }^{1} \mathrm{H} \mathrm{NMR}$ $\left(400 \mathrm{MHz}, \mathrm{DMSO}-\mathrm{d}_{6}\right) \delta: 4.45$ and $4.51\left(\mathrm{~d}-\mathrm{d}, 2 \mathrm{H}, \mathrm{N}^{+} \mathrm{CH}_{2}\right.$, $\mathrm{J}=16.6 \mathrm{~Hz}$ ), 4.97 and $5.02\left(\mathrm{~d}-\mathrm{d}, 2 \mathrm{H}, 3-\mathrm{CH}_{2}, \mathrm{~J}=14.3 \mathrm{~Hz}\right.$ ), 6.96-8.49 (m, 14H, aromatic protons), $7.96(\mathrm{~s}, 1 \mathrm{H}, \mathrm{OH})$. ${ }^{13} \mathrm{C}$ NMR spectrum $(100 \mathrm{MHz}$, DMSO-d6) $\delta: 51.11,57.27$, $99.34,106.6,107.9,115.0,126.1,127.1,128.0,128.9$, 130.0, 132.0, 133.4, 161.3, 170.8.

Method B: $1.1 \mathrm{ml}(0.02 \mathrm{~mol})$ of benzylamine were added to solid 2-bromo-1-(2-oxo-2-phenylethyl) pyridinium bromide $5(3.57 \mathrm{~g}, 0.01 \mathrm{~mol}$. The reaction mixture was ground. After the exothermic reaction, the mixture was kept for $24 \mathrm{~h}$ at room temperature. Then it was suspended in water, the precipitate was filtered and dried. Yield $0.88 \mathrm{~g}$ $(23 \%)$. M.p. $=467-468 \mathrm{~K}$.

Synthesis of 1-benzyl-2-hydroxy-2-(4-methylphenyl)2,3-dihydroimidazo[1,2-a]pyridinium bromide $\mathbf{4 b}$ was carried out similar to bromide $4 \mathbf{a}$ using $1.84 \mathrm{~g}(0.01 \mathrm{~mol})$ of amidine 1a and $2.13 \mathrm{~g}(0.01 \mathrm{~mol})$ of $\alpha$-bromo-4-methylacetophenone 2b. Yield $2.98 \mathrm{~g}(75 \%)$. M.p. $=478-479 \mathrm{~K}$. Anal. Calcd. for $\mathrm{C}_{21} \mathrm{H}_{21} \mathrm{BrN}_{2} \mathrm{O}, \%: \mathrm{N}=7.05 \mathrm{Br}=20.1$. Found, $\%: \mathrm{N}=7.21 \mathrm{Br}=20.3 .{ }^{1} \mathrm{H}$ NMR $\left(400 \mathrm{MHz}, \mathrm{DMSO}-\mathrm{d}_{6}\right) \delta$ : $2.37\left(\mathrm{~s}, 3 \mathrm{H}, \mathrm{CH}_{3}\right), 4.46$ and $4.52\left(\mathrm{~d}-\mathrm{d}, 2 \mathrm{H}, \mathrm{N}^{+} \mathrm{CH}_{2}, \mathrm{~J}=16.9\right.$ $\mathrm{Hz}$ ), 5.04 and 5.27 (d-d, 2H, 3- $\left.\mathrm{CH}_{2}, \mathrm{~J}=14.2 \mathrm{~Hz}\right), 6.78-8.76$ (m, $9 \mathrm{H}$, aromatic protons), 7.18 and $7.66\left(\mathrm{~d}-\mathrm{d}, 4 \mathrm{H}, \mathrm{C}_{6} \mathrm{H}_{4}\right.$, $\mathrm{J}=8.8 \mathrm{~Hz}), 7.94(\mathrm{~s}, 1 \mathrm{H}, \mathrm{OH}) .{ }^{13} \mathrm{C}$ NMR spectrum $(100 \mathrm{MHz}$, DMSO-d6) $\delta: 20.95,51.23,57.31,99.53,106.5,108.0$, $115.1,126.2,127.2,127.7,128.1,129.2,130.8,133.4$, $140.8,161.5,170.6$.

Synthesis of 1-benzyl-2-hydroxy-2-(4-ethylphenyl)2,3-dihydroimidazo[1,2-a]pyridinium bromide $\mathbf{4 c}$ was carried out similar to bromide $4 a$ using $1.84 \mathrm{~g}(0.01 \mathrm{~mol})$ of amidine $1 \mathrm{a}$ and $2.27 \mathrm{~g} \quad(0.01 \mathrm{~mol})$ of $\alpha$-bromo-4ethylacetophenone 2c. Yield 2.84 g $(69 \%)$. M.p. $=474$ $475 \mathrm{~K}$. Anal. Calcd. for $\mathrm{C}_{22} \mathrm{H}_{23} \mathrm{BrN}_{2} \mathrm{O}, \%$ : $\mathrm{N}=6.81 \mathrm{Br}=19.4$. Found, \%: $\mathrm{N}=6.98 \mathrm{Br}=19.7$. ${ }^{1} \mathrm{H}$ NMR $(400 \mathrm{MHz}$, DMSO$\left.\mathrm{d}_{6}\right) \delta: 1.25\left(\mathrm{t}, 3 \mathrm{H}, \mathrm{CH}_{2} \mathrm{CH}_{3}\right), 2.66\left(\mathrm{q}, 2 \mathrm{H}, \mathrm{CH}_{2} \mathrm{CH}_{3}\right), 4.46$ and $4.53\left(\mathrm{~d}-\mathrm{d}, 2 \mathrm{H}, \mathrm{N}^{+} \mathrm{CH}_{2}, \mathrm{~J}=16.8 \mathrm{~Hz}\right), 5.02$ and 5.21 (d-d, $\left.2 \mathrm{H}, 3-\mathrm{CH}_{2}, \mathrm{~J}=14.1 \mathrm{~Hz}\right), 6.84-8.70(\mathrm{~m}, 9 \mathrm{H}$, aromatic protons), 7.20 and $7.66\left(\mathrm{~d}-\mathrm{d}, 4 \mathrm{H}, \mathrm{C}_{6} \mathrm{H}_{4}, \mathrm{~J}=8.9 \mathrm{~Hz}\right.$ ), 7.91 (s, $1 \mathrm{H}, \mathrm{OH}) .{ }^{13} \mathrm{C}$ NMR spectrum $(100 \mathrm{MHz}$, DMSO-d6) $\delta$ : $15.90,28.80,51.12,57.19,99.28,106.4,107.7,114.9$, $126.0,127.0,127.7,128.0,128.7,130.3,133.3,143.9$, 161.2, 170.5.

Synthesis of 1-benzyl-2-hydroxy-2-(4-methoxyphenyl)2,3-dihydroimidazo[1,2-a]pyridinium bromide 4d was carried out similar to bromide 4a using $1.84 \mathrm{~g}(0.01 \mathrm{~mol})$ of amidine $1 \mathrm{a}$ and $2.29 \mathrm{~g} \quad(0.01 \mathrm{~mol})$ of $\alpha$-bromo-4methoxyacetophenone 2d. Yield 2.6 g $(65 \%)$. M.p. $=476$ $477 \mathrm{~K}$. Anal. Calcd. for $\mathrm{C}_{21} \mathrm{H}_{21} \mathrm{BrN}_{2} \mathrm{O}_{2}$, \%: $\mathrm{N}=6.77$ $\mathrm{Br}=19.3$. Found, \%: $\mathrm{N}=6.63 \mathrm{Br}=19.5 .{ }^{1} \mathrm{H}$ NMR $(400 \mathrm{MHz}$, DMSO- $\left._{6}\right) \delta: 3.81\left(\mathrm{~s}, 3 \mathrm{H}, \mathrm{OCH}_{3}\right), 4.46$ and $4.52(\mathrm{~d}-\mathrm{d}, 2 \mathrm{H}$, $\mathrm{N}^{+} \mathrm{CH}_{2}, \mathrm{~J}=16.8 \mathrm{~Hz}$ ), 5.05 and 5.24 (d-d, 2H, 3- $\mathrm{CH}_{2}$, $\mathrm{J}=14.2 \mathrm{~Hz}$ ), $6.77-8.76(\mathrm{~m}, 9 \mathrm{H}$, aromatic protons), 6.89 and $7.69\left(\mathrm{~d}-\mathrm{d}, 4 \mathrm{H}, \mathrm{C}_{6} \mathrm{H}_{4}, \mathrm{~J}=8.8 \mathrm{~Hz}\right), 7.91(\mathrm{~s}, 1 \mathrm{H}, \mathrm{OH}) .{ }^{13} \mathrm{C} \mathrm{NMR}$ spectrum (100 MHz, DMSO-d6) $\delta: 51.07,55.14,57.28$, $99.37,106.6,107.9,113.8,115.0,126.1,127.7,127.8$, 128.0, 133.4, 160.3, 161.4, 170.9 .

Synthesis of 1-benzyl-2-hydroxy-2-(4-bromophenyl)2,3-dihydroimidazo[1,2-a]pyridinium bromide $4 \mathbf{e}$ carried out similar to bromide $4 \mathrm{a}$ using $1.84 \mathrm{~g}(0.01 \mathrm{~mol})$ of amidine $\mathbf{1 a}$ and $2.78 \mathrm{~g}(0.01 \mathrm{~mol})$ of $\alpha, 4$-dibromoacetophenone $\mathbf{2 e}$. Yield 3.56 g (77\%). M.p. $=493-495$ K. Anal. Calcd. for $\mathrm{C}_{20} \mathrm{H}_{18} \mathrm{Br}_{2} \mathrm{~N}_{2} \mathrm{O}, \%$ : $\mathrm{N}=6.06 \mathrm{Br}=34.6$. Found, \%: $\mathrm{N}=6.23$ $\mathrm{Br}=34.3 .{ }^{1} \mathrm{H}$ NMR $\left(400 \mathrm{MHz}, \mathrm{DMSO}-\mathrm{d}_{6}\right) \delta: 4.51(\mathrm{~s}, 2 \mathrm{H}$, $\mathrm{N}^{+} \mathrm{CH}_{2}$ ), 5.05 and 5.24 (d-d, 2H, 3-CH $2, \mathrm{~J}=14.1 \mathrm{~Hz}$ ), 6.858.78 ( $\mathrm{m}, 9 \mathrm{H}$, aromatic protons), 7.48 and $7.76(\mathrm{~d}-\mathrm{d}, 4 \mathrm{H}$, $\left.\mathrm{C}_{6} \mathrm{H}_{4}, \mathrm{~J}=8.9 \mathrm{~Hz}\right), 8.08(\mathrm{~s}, 1 \mathrm{H}, \mathrm{OH}) .{ }^{13} \mathrm{C} \mathrm{NMR}$ spectrum (100 MHz, DMSO-d6) $\delta: 51.10,57.31,99.35,106.7,108.1$, $115.2,126.0,127.6,127.9,129.1,131.3,131.9,133.4$, $161.5,171.0$

\subsection{Microbiology Measurements}

The test-cultures were sulfate-reducing bacteria of Desulfovibrio sp. M-4.1 and Desulfomicrobium sp. TC 4 strains. Strain Desulfovibrio sp. M-4.1 was collected from 
sulfidogenic natural group of ferrosphere and identified with molecular-biological methods [19]. Strain Desulfomicrobium sp. TC4 was obtained from the corrosion product of brass tubes in water thermal networks and taken from the collection of the Department of General and Soil Microbiology, D. K. Zabolotny Institute of Microbiology and Virology, the National Academy of Sciences of Ukraine. Antibacterial properties of imidazopyridinium (4a, 4e, $\mathbf{4 d}$ ) bromides were defined with agar diffusion method using holes in agar, to which ethanol solutions of the studied salts at $1.0 \%$ concentration were added. Anaerobic conditions for the growth of sulphate-reducing bacteria were created with the cover glass and polymers plate method (Sturm's Method in Doody's Modification). The opening between the cover glass plate and the dish was filled with the sterile solution of agar-agar ( $2.0 \%$ concentration). The control was the growth of bacteria under the influence of alcohol solution $(96.0 \%)$. The sensitivity of sulfatereducing bacteria to imidazopyridinium derivatives was estimated according to the diameter of growth retardation zone. During the study of steel microbial corrosion, the number of sulfate-reducing bacteria in plankton and biofilm was defined using the serial dilution method. The biofilm cells, which appeared on the surface of steel samples during tests, were gathered into the fixed volume $(20 \mathrm{ml})$ of $0.1 \mathrm{~N}$ phosphate buffer $(\mathrm{pH} 7)$ with the help of ultrasound $(25 \mathrm{kHz}, 30 \mathrm{~s})$ twice with the $60 \mathrm{~s}$ interval using UZM-003/n.

\subsection{Corrosive Measurements}

Gravimetric corrosive study was carried out in sealed containers with the coupons of $19 \mathrm{~cm}^{2}$ mild St3ps steel (widely used in constructions, exploited under the conditions suitable for SRB functioning) in the sterile nutrient Postgate "B" medium, inoculated with binary SRB culture. Desulfomicrobium sp. TC 4 and Desulfovibrio sp. M-4.1 cultures were mixed at the percentage ratio of 50:50; 70:30 and 30:70, respectively. The titre of SRB in the subculture was $10^{6}-10^{8} \mathrm{cell} / \mathrm{ml}$. The compound concentrations were $0.05 \mathrm{~g} / 1(0.005 \%)(4 \mathrm{~d})$ and $1.0 \mathrm{~g} / \mathrm{l}$ $(0.1 \%)(4 a)$; exposure time was $240 \mathrm{~h}$; temperature was $301 \mathrm{~K}$.

Corrosion rate $(k)$ with or without the inhibitors, corrosion inhibition coefficient $(\gamma)$, and inhibition efficiency (IE) were calculated according to Eqs. (1), (2) and (3), respectively:

$$
\begin{gathered}
k=\frac{\Delta m}{S \cdot \tau} \\
\gamma=k / k^{\prime} \\
I E=(1-1 / \lambda) \cdot 100 \%
\end{gathered}
$$

where $\Delta m$ is a weight loss, $\mathrm{g} ; S$ is an area, $\mathrm{m}^{2} ; \tau$ is exposure time, h; $k$ and $k$ are the corrosion rates with and without the inhibitor, respectively.
The concentration of biogenic hydrogen sulfide was measured by iodometric titration. The degree of influence $(S)$ of the studied salts on bacteria sulfatereduction was calculated using Eq. (4):

$$
S=\frac{C-C^{\prime}}{C} \cdot 100 \%
$$

where $C$ and $C^{\prime}$ are the average hydrogen sulphide concentrations with and without the inhibitor, respectively, $\mathrm{mg} / \mathrm{l}$.

During the experiments the following methods of hydrogen sulfide preservation were used: minimum sampling time, hermetically sealed corks, shaking and mixing with a sterile pipette before sampling.

Statistical analysis of experimental data was conducted for the significance level of 0.05 considering normal $t$-distribution; testing was conducted three times. Relative error is less than $10 \%$.

\section{Results and Discussion}

The study of the alkylation of 2-aminopyridine with various halogen-carbonyl compounds, which was started by Chichibabin [20], and flowing through the nitrogen atom in the cycle, has resulted in many practical compounds.

We have shown that the condensation of 2benzylaminopyridine 1 with-halogen ketones proceeds at the nitrogen atom in the cycle with the formation of the corresponding salts 4a-e (Scheme 1), which can exist in two tautomeric forms.

The analysis of the PMR spectra data indicates the existence of salts 4a-e in a bicyclic form. Thus, in the PMR spectra of the protons of both methylene groups of compounds 4a-e, they appear as characteristic signals of the AB-system $(J=14.1-16.9 \mathrm{~Hz})$. It should be noted that the degree of magnetic nonequivalence of the protons of the acyclic group $\mathrm{CH}_{2}$ depends on the nature of the substituent $\mathrm{R}$. So, with the electron-withdrawing substituent $\mathrm{R}=\mathrm{Br}$, the signals of these protons have the form of a broadened singlet in the region of $4.51 \mathrm{ppm}$. The cyclic form is also confirmed by the presence of one-proton singlet in the area of 7.91-8.08 ppm, which with confidence can be attributed to the hydrogen atom of the hydroxyl group in position $\mathbf{2}$ of the imidazo[1,2-a] pyridine system. When adding a small amount of $\mathrm{D}_{2} \mathrm{O}$, this signal disappears due to deutero exchange.

The direction of alkylation of the starting 2benzylpyridine 1 precisely on the nitrogen atom in the cycle was proved by the method of counter synthesis. Thus, by the interaction of 1-phenacyl-2-bromopyridinium bromide with benzylamine, 1-benzyl-2-hydroxy-2-phenyl2,3-dihydroimidazo[1,2-a]pyridinium bromide 4a was obtained (Scheme 2). The physicochemical constants of compound $4 \mathbf{a}$ obtained by different methods are the same. 
<smiles>CCOC(=O)C(=O)OCc1ccccc1</smiles>

1 b<smiles>[R]c1ccc(C(=O)Cn2ccccc2=NCc2ccccc2)cc1</smiles>

(3 a-e)<smiles>[R]c1ccc(C2(O)CN3C=CC=CC3=[N+]2Cc2ccccc2)cc1</smiles>

4 a-e

where $\mathrm{R}=\mathrm{H}(\mathrm{a}), \mathrm{CH}_{3}$ (b), $\mathrm{CH}_{2} \mathrm{CH}_{3}(\mathrm{c}), \mathrm{OCH}_{3}$ (d) and $\mathrm{Br}(\mathrm{e})$

Scheme 1<smiles>O=C(C[n+]1ccccc1Br)c1ccccc1</smiles>

5

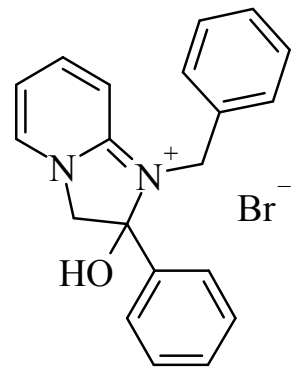

$4 \mathbf{a}$

Scheme 2

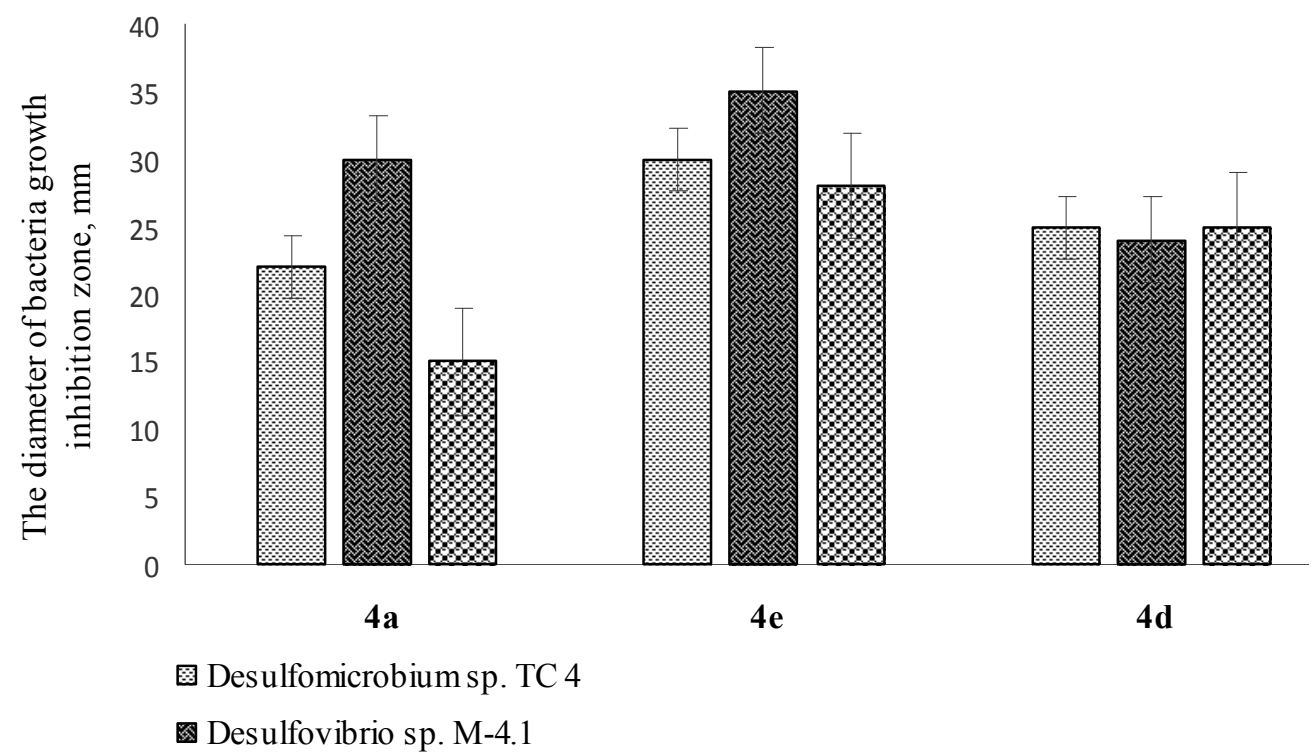

Desulfomicrobium sp. TC 4 : Desulfovibrio sp. M-4.1 (50\%:50\%)

Fig. 1. Antibacterial properties of 2,3-dihydroimidazo[1,2-a] pyridinium bromides against sulfate-reducing bacteria 
The antibacterial properties of dihydroimidazo[1,2a]pyridinium bromides $(\mathbf{4 a}, \mathbf{4 e}, \mathbf{4 d})$ against the monocultures of Desulfomicrobium sp.TC4 and Desulfovibrio sp.M-4.1 strains, and also against the binary culture of the indicated strains in the percentage ratio of 50:50 (Fig. 1) were assessed. Alcohol solution (control), which is used as organic solvent to imidazopyridinium bromides, does not hamper the growth of sulfate-reducing bacteria. It was defined that the studied SRB cultures are sensitive to compounds $4 \mathbf{a}, \mathbf{4 e}, \mathbf{4 d}$ : the diameter of bacteria growth retardation zone is $15.0-35.0 \mathrm{~mm}$. With $\mathbf{4 a}$ and $\mathbf{4 e}$ the biocidal activity against monocultures of sulfate-reducing bacteria is higher compared with the binary culture. Growth inhibition activity of $\mathbf{4 d}$ compound against monoand binary bacteria cultures turned out to be approximately the same: the diameter of the zone is up to $25 \mathrm{~mm}$ (Fig. 1).

It is known that the mechanism of drugs antibacterial activity may be caused by a violation of the protein and nucleic acids synthesis in the microbe cell [8]. Primarily, the biocidal activity of quaternary imidazopyridinium salts, which contain a positively charged nitrogen atom, is caused by the electrostatic interaction of molecules with a negatively charged outer membrane of gram-negative bacteria cells, in particular, sulfate-reducing strains Desulfomicrobium sp.TC4 and Desulfovibrio sp.M4.1. This leads to the destruction of the composition of the outer membrane and makes the bacterial cell more sensitive to the salts.

The existing bactericidal effect of the tested 2,3dihydroimidazo[1,2-a]pyridinium bromides is promising for their study as inhibitors of steel microbial corrosion.

To study the process of microbial corrosion of steel, induced by the binary culture of sulfate-reducing bacteria of Desulfomicrobium sp.TC4 and Desulfovibrio sp.M-4.1 strains with different ratio, the pyridinium bromide $4 \mathbf{d}(50 \mathrm{mg} / \mathrm{l})$ was chosen. The effect of the $\mathbf{4 d}$ compound on the production of biogenic hydrogen sulfide (the main product of the sulfate-reducing bacteria vital activity) by the binary culture is demonstrated in Fig. 2 . Significant retardation of the sulfate-reducing activity of the binary culture was established: hydrogen sulfide concentration decreases by 2.4-4.5 times (Fig. 2). At the same time, the minimal hydrogen sulfide concentration was noted in the binary culture at the ratio of 50:50; the degree of sulfate reduction suppression was $78 \%$.

With the compound $\mathbf{4 d}$ at concentration of $50 \mathrm{mg} / \mathrm{l}$ the number of plankton forms of sulfate-reducing bacteria cells in the composition of the binary cultures is at the control level and is up to $10^{10} \mathrm{cell} / \mathrm{ml}$. Simultaneously, a significant decrease in the concentration of biogenic hydrogen sulfide (the degree of effect on sulfate reduction is $58-78 \%$ ) is observed. This indicates the low level of sulfate-reducing activity of SRB and the degree of their adaptation to the action of the compounds, which will lead to the further inability of the bacteria to form an active biofilm on the metal surface.

As a part of biofilm, bacteria acquire qualitatively new properties compared with the microorganisms in plankton form. Biofilm bacteria are more resistant to the activity of organic compounds - biocides, which enables them to remain viable at concentrations of compounds above doses which inhibit the plankton forms [21]. At the concentration of $50 \mathrm{mg} / \mathrm{l}$ of compound $\mathbf{4 d}$ there is a little effect on the quantity of SRB cells in the biofilm: their number is $10^{5}-10^{9} \mathrm{cell} / \mathrm{cm}^{2}$, which is at the control level. It should be mentioned that the stated concentration of the biocide is not sufficient to sustain the stable inhibition of bacterial growth.

When the concentration of imidazopyridinium quaternary salt (for the screening tests the compound $\mathbf{4 a}$ was chosen) increases to $1.0 \mathrm{~g} / 1$, the decrease of the number of SRB cells in the plankton and biofilm is observed under the microbial corrosion of steel, induced by the binary culture of bacteria with different ratio of Desulfomicrobium sp.TC4:Desulfovibrio sp. M-4.1 (Figs. 3a, 3b) strains. The effect of the compound on the plankton and biofilm bacteria forms is different. The decrease of the bacteria cells number in plankton is more evident (by 6-7 orders) (Fig. 3a). In the binary cultures of SRB of Desulfomicrobium sp. TC4:Desulfovibrio sp. M-4.1 strains with the percentage ratio of 50:50 and 30:70 no viable cells in plankton were identified, which correlates with the $88.0 \%$ and $80.5 \%$ reduction in hydrogen sulfide formation, respectively (Table).

With the presence of compound 4a in the corrosive medium the number of bacteria cells in the biofilm decreases by $3-4$ orders (Fig. $3 b$ ). In the binary culture of SRB with the percentage ratio 50:50 the biofilm cells are not identified under the effect of imidazopyridinium bromide 4a. Thus, the compound $\mathbf{4 a}$, extracted in the screening experiments, at the concentration of $1.0 \mathrm{~g} / 1$ demonstrates bactericidal effect against SRB of Desulfomicrobium $\quad$ sp. TC4:Desulfovibrio $\quad$ sp. M-4.1 strains and antibiofilm properties under the steel microbial corrosion.

It is most practical to add to the corrosive medium such compounds, which simultaneously inhibit the activity of corrosion-aggressive bacteria and reduce the rate of steel microbial corrosion. Anticorrosive properties of imidazopyridinium $\mathbf{4 a}$ quaternary salt under the microbial corrosion of steel, induced with the binary culture of sulfate-reducing strains Desulfomicrobium sp. TC4:Desulfovibrio sp. M-4.1 is shown in the Table. The steel biocorrosion rate in the presence of compound $\mathbf{4 a}$ is inhibited by $2.80-3.40$ times, the protective effect is $64.3-$ $70.6 \%$. 


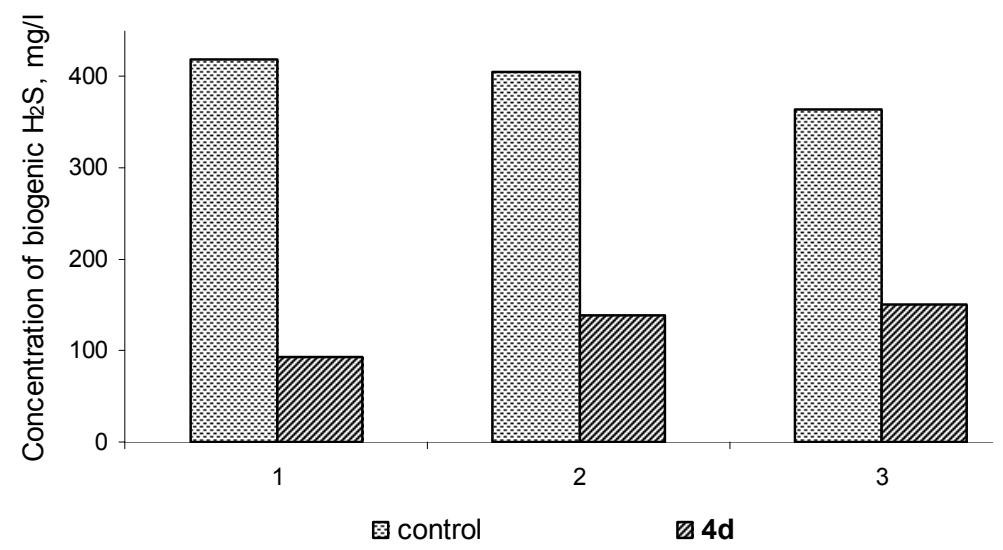

Fig. 2. Hydrogen sulfide concentration under microbial corrosion of steel, induced by the binary culture of sulfate-reducing bacteria with 50:50 (1); 70:30 (2) and 30:70 (3) percentage ratio of Desulfomicrobium sp.TC4 and Desulfovibrio sp.M-4.1 strains under the effect of bromide 4d

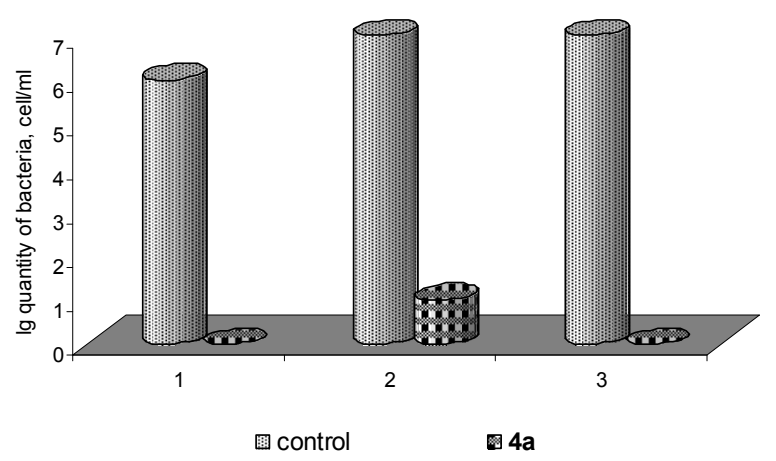

a)

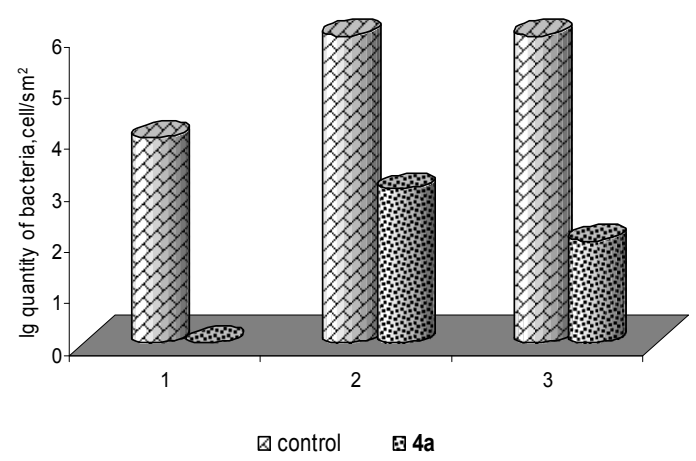

b)

Fig. 3. Number of bacteria cells in plankton (a) and biofilm (b) without (control) and in the presence of compound 4a under microbial corrosion of steel, induced by the binary culture of SRB with 50:50 (1); 70:30 (2) and 30:70 (3) percentage ratio of Desulfomicrobium sp.TC4 and Desulfovibrio sp.M-4.1

Table

Indices of microbial corrosion of steel, induced with the binary culture of sulfate-reducing bacteria in the presence of 1-benzyl-2-hydroxy-2-phenyl-2,3-dihydroimidazo[1,2-a]pyridinium bromide (4a)

\begin{tabular}{|c|c|c|c|}
\hline \multirow{2}{*}{ Indices } & \multicolumn{3}{|c|}{ Bacteria culture } \\
\cline { 2 - 4 } & \multicolumn{3}{|c|}{ Desulfomicrobium sp. TC 4:Desulfovibrio sp. M-4.1 percentage ratio } \\
\cline { 2 - 4 } & $50: 50$ & $70: 30$ & $30: 70$ \\
\hline$S, \%$ & 88.0 & 92.4 & 80.5 \\
\hline$\gamma$ & 3.14 & 3.40 & 2.80 \\
\hline$I E, \%$ & 68.2 & 70.6 & 64.3 \\
\hline
\end{tabular}

Anticorrosive properties of 2,3-dihydroimidazo [1,2-a]pyridinium bromides under steel microbial corrosion can be explained by their ability to inhibit the sulfate-reducing activity of bacteria (up to $92.4 \%$, see the Table), to reduce the adhesion of bacteria to steel (Fig. 3b) and to form the adsorption films on the metal surface. This leads to the reduction of hydrogen release on the steel surface, which in turn inhibits the catalytic function of SRB as depolarizers of the cathode process.
To sum up, the conducted research offers the experimental grounds for the search of compounds with antibacterial and anticorrosive properties among 2,3dihydroimidazo[1,2- $a]$ pyridinium bromides. Their further in-depth study is promising for the development of the new inhibitors-biocides of the microbial corrosion of steel, induced with the SRB of Desulfomicrobium and Desulfovibrio strains. 


\section{Conclusions}

For the first time a series of 2,3-dihydroimidazo $[1,2-a]$ pyridinium bromides was synthesized, the structure and individuality of which was confirmed with the element analysis and ${ }^{1} \mathrm{H}$ NMR spectroscopy. It has been established that the compounds demonstrate the antibacterial activity against SRB of Desulfomicrobium and Desulfovibrio strains. Under the steel microbial corrosion, the studied salts demonstrate the most distinct activity on the plankton bacteria cells, which leads to inhibition of their functional activity and inability to form strong biofilm on a metal surface. At the same time, the production of biogenic hydrogen sulfide is inhibited by imidazopyridinium bromides to $78.0 \%$ at the concentration of $50 \mathrm{mg} / \mathrm{l}$ and to $92.4 \%$ at $1.0 \mathrm{~g} / \mathrm{l}$. It was defined that the studied 1-benzyl-2-hydroxy-2-phenyl-2,3-dihydroimidazo [1,2-a]pyridinium bromide has antibiofilm properties: the number of sulfate-reducing bacteria in the biofilm in the binary cultures of Desulfomicrobium sp. TC 4 and Desulfovibrio sp. M-4.1 strains decreases by 3-4 orders, ensuring the protective effect up to $70.6 \%$ at the compound concentration of $1.0 \mathrm{~g} / 1$.

\section{References}

[1] Bellani P., Clavenna G., Sosio A.: Farmaco Sci., 1984, 39, 846.

[2] Kiffer D., Minard P.: Biochemical Pharmacology, 1986, 35, 2527. https://doi.org/10.1016/0006-2952(86)90050-X

[3] Patnaik S., Marugan J.J., Liu K. et al.: J. Med. Chem, 2013, 56

(22), 9045. https://doi.org/10.1021/jm400904m

[4] Kuhla D., Donald E.: Pat. US 4141898A, Publ. Febr. 27, 1977.

[5] Babaev E., Bush A., Orlova I. et al.: Izvestiya Akad. Nauk,

2005, 1, 226.

[6] Rudko A., Chernyuk I., Rozum Yu.: Zh. Org. Khim., 1968, 38, 1275.

[7] Kuhla D., Watson H.: J. Heterocycl. Chem., 1978, 15 (10), 1149. https://doi.org/10.1002/jhet.5570150716

[8] Andreyuk K., Kozlova I., Kopteva Zh. et al.: Mikrobna Koroziya Pidzemnih Sporud. Naukova dumka, Kyiv 2005.

[9] Kurmakova I., Demchenko N., Bondar O., Vorobyova V.:

Chem. Chem. Technol., 2018, 12, 519.

https://doi.org/10.23939/chcht12.04.519
[10] Kurmakova I., Bondar O., Polevichenko S., Demchenko N.: Chem. Chem. Technol., 2017, 11, 314.

https://doi.org/10.23939/chcht11.03.314

[11] Demchenko N., Tkachenko S., Lifar M., Tretiak O.:

Mizhnarodna Konferencija "Problemy koroziji i protykorozijnogho zakhystu materialiv", Ukraine, Lviv 2018, 199.

[12] Yeromina H., Demchenko N., Kiz O. et al.: Chem. Chem.

Technol., 2019, 13, 150. https://doi.org/10.23939/chcht13.02.150

[13] Purish L., Kozlova I., Pogrebova I.: Praktika

Protivokorrozionnoi Zaschity, 2013, 67, 18.

[14] Cho D., Parthasarathi R., Pimentel A. et al.: J. Org. Chem., 2010, 75, 6549. https://doi.org/10.1021/jo1012509

[15] Akbarzadeh A., Soleymani,R., Taheri M., et al.: Orient. J. Chem., 2012, 28, 153. https://doi.org/10.13005/ojc/280122

[16] Yurttaş L., Özkay Y., Duran M. et al.: Phosphorus. Sulfur, 2016, 191, 1166. https://doi.org/10.1080/10426507.2016.1150277

[17] Yang Z., Huang N., Xu B. et al.: Molecules, 2016, 21, 232. https://doi.org/10.3390/molecules21030232

[18] Chen J., Liu D., Butt N. et al.: Angew. Chem. Int. Edn., 2013, 52, 11632. https://doi.org/10.1002/anie.201306231

[19] Demchenko N., Kurmakova I., Tretyak O.: Mikrobiol. i

Biotekhnolog., 2013, 4, 90.

[20] Chichibabin A.: Zh. Russk. Fiz.- Him. Obschestva, 1926, 58, 1159.

[21] Vinnik Yu., Serova E.: Sovremennyie Problemyi Nauki i

Obrazovaniya, 2013. http://www.science-

education.ru/ru/article/view?id=10371

Received: May 16, 2019 /Revised: August 29, 2019 / Accepted: December 12, 2019

\section{СИНТЕЗ, АНТИБАКТЕРІАЛЬНА ТА ПРОТИКОРОЗІЙНА ДІЇ БРОМІДІВ 2,3-ДИГІДРОІМІДАЗО[1,2-а]ПІРИДИНІЮ}

Анотація. Синтезовано ряд нових бромідів 2,3-дигідроімідазо[1,2-а]піридинію, які проявляють антибактеріальні властивості щооо сульфатвідновлювальних бактерій родів Desulfomicrobium ma Desulfovibrio та пригнічують ӥх функціонування за умов мікробної корозії сталі у складі бінарної культури. Сполукам притаманні антибіоплівкові та протикорозивні властивості в середовищі з сульфатвідновлювальними бактеріями, ступінь захисту сталі від біокорозії становить до 70,6\%.

Ключові слова: броміди 2,3-дигідроімідазо[1,2-а]піридинію, сульфатвідновлювальні бактерії, итам Desulfovibrio sp. M-4.1, итам Desulfomicrobium sp. TC 4, інгібітори-біочиди, біокорозія. 